Radek Toman

\title{
Aspekty bydlení ve výškových budovách, definované na základě analýzy a pozorování čínských měst
}

Klíčová slova: Mrakodrap; Čína; Urbanizace.

Kontakt: arch.radektoman@gmail.com

Školitel: Iva Poslušná

Tematický okruh: Architektura

Aspects of High-Rise Housing, Based on Analysis and Observation of Chinese Cities

"Throughout the city, whole blocks are being flattened, turning parts of the former "Paris of the East" into huge construction sites - a chorus of cranes, jack-hammers and bulldozers chiselling out the foundations of skyscrapers, elevated expressways and subway tunnels. Architects are having their fling with modernism - designing huge glass-faced office complexes and luxury apartment blocks." [1] 
„Všude ve městě jsou celé bloky srovnávány se zemí, části, které vytvořily ,Paříz východu', se stávají obrovským staveništěm - orchestrem sbiječek, jeřábů a buldozerů vydlabávajících základy pro nové mrakodrapy, dálniční mosty a tunely metra. Architekti zde dělají své pokusy s modernismem, navrhují obrovské prosklené fasády kancelárských komplexů a luxusních bytových bloků." [1]

$\mathrm{S}$ čínským pozvolným přechodem z plánované ekonomiky směrem k tržní ekonomice procházejí čínská města podstatnými změnami. Jádrem této přeměny jsou velkoměsta, která nyní hrají významnou roli v celkovém ekonomickém rozvoji. V plánu jedenácté pětiletky (pro roky 2005 až 2010) byl zvyšující se podíl urbanizace zahrnut jako hlavní politický nástroj zajištující ekonomický růst. V následující dvanácté pětiletce (schválené na Všelidovém shromáždění 4 . března 2011) se počítá s nárůstem městského obyvatelstva na hodnotu 51,5 \% v roce 2015, ale fakticky už na konci roku 2013 dosáhl hodnoty 53,7 \%, [2] dnes tedy ve městech žije téměř tři čtvrtě miliardy Číňanů. Dle odhadů dosáhne míra urbanizace hodnoty $75 \%$ do roku 2050, v ten moment bude městský sektor zabírat už více než 95 \% čínské ekonomiky. [3]

„Tato země podstupuje jednu z největších populačních migrací v lidské historii. V několika príśtích desetiletích se 500 milionů lidí přesune ze zemědělských oblastí do prưmyslových oblastí, environmentální dopady toho jsou kategoricky globální." [4]

„V roce 1989 měl Šen-čen ambiciózní plán, který počítal s nárůstem populace z 30 tisíc na 1 milion během deseti let. V roce 2000 však byla jeho oficiální populace 10 milionů obyvatel." [5]

Členství ve World Trade Organization (WTO) významně podpořilo zapojení čínské ekonomiky do globální ekonomiky. Nejrychleji se rozvíjející čínská města jsou zároveň centry globální produkce komodit.

Dá se říci, že takto rychlý rozvoj je něco, co lidská společnost ještě nezažila. Tato transformace znamenala také masivní změnu typologie čínských měst. Tradiční městské formy se udržely až do roku 1979. Před zavedením reforem byl Peking tvořen téměř jen starými jedno- nebo dvoupodlažními domy, avšak ekonomické změny přinesly během několika málo let posun v bytové výstavbě od jednopodlažních domů až k výškové výstavbě obytných mrakodrapů.

Dizertační práce „Aspekty bydlení ve výškových budovách“ se zabývá důvody městské přeměny a jejími vlivy na bydlení a život obyvatel velkých měst. 


\section{ZKRÁCENÝ SOUPIS ZDROJŮ}

[1] Pamela Yatsko; Field of dreams: can Shanghai re-emerge as a key financial centre?; Far East Economic Review; 18. července 1996; s. 69.

[2] http://news.xinhuanet.com/english/china/2014-03/16/c_133190605.htm; staženo: 3.5.2015.

[3] Fulong Wu, Jiang Xu, Anthony Gar-On Yeh; Urban Development in Post-Reform China; New York; 2007; IBSN: 0-415-39359-0; s. 1.

[4] Steven Holl; Urbanisms Working with Doubt; New York; 2009; IBSN: 9781-56898-679-1; s. 11.

[5] http://asiasociety.org/history-city-without-history; staženo: 20.5.2015.

BOUMAN, Ole (editor). Volume 8, Ubiquitous China. 1. vyd. Die Keure; 2006; IBSN: 074470078760008.

CÍLEK, Václav. Krajiny vnitřní a vnější. 2. vyd. Dokořán, Praha, 2010; ISBN: 80-7363-042-7.

FRIEDMANN, John. China's Urban Transition. 1. vyd. University of Minnesota Press, Mineapolis, 2005; ISBN: 0-8166-4615-5.

HOLL, Steven. Urbanisms, Working with Doubt. 1. vyd. Princeston Architectural Press, New York, 2009; ISBN: 978-1-56898-679-1.

KARLACH, Jan. Čína, Střípky z jižního Podnebesí. 1. vyd. Gasset, Praha, 2012; ISBN: 978-80-87079-18-8.

\section{FOTOGRAFIE}

[1] http://dsr.nii.ac.jp/toyobunko/II-11-D-802/V-7/page-hr/0003.html.en; staženo: 20.5.2015

[2] http://www.thegoldenscope.com/2014/05/a-gweilo-in-1980s-china-chapter-17/; staženo: 20.5.2015

[3-6] Foto: archiv autora 


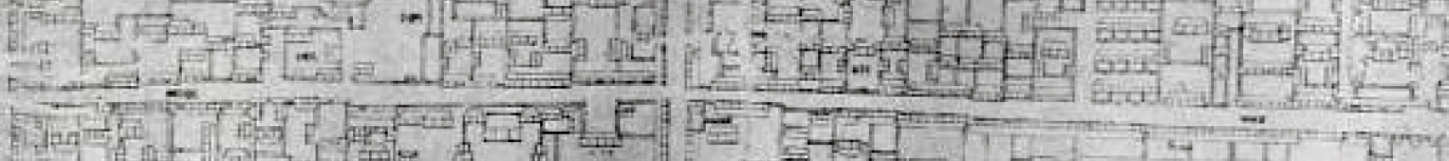

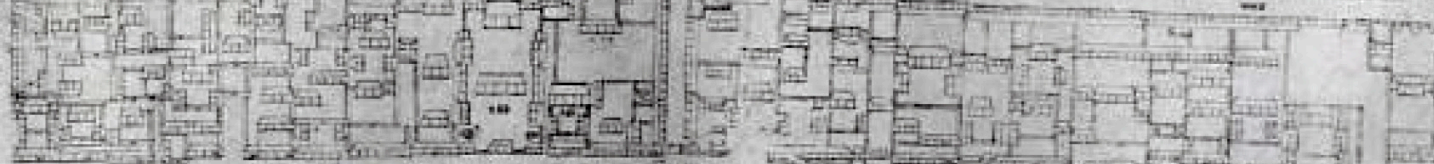
A

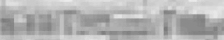

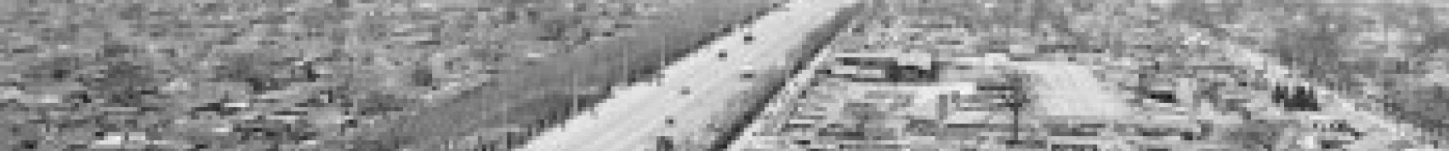

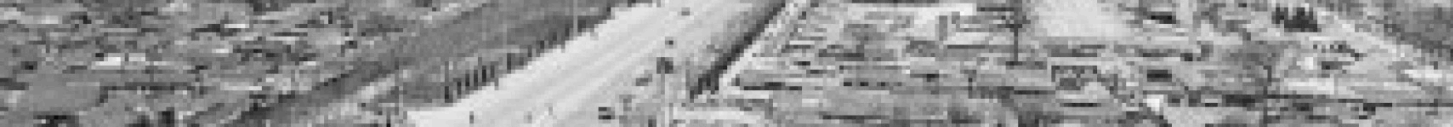

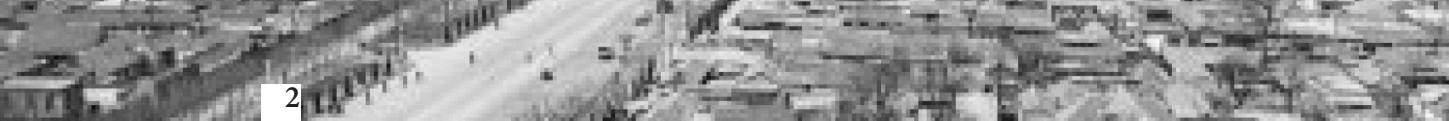
ar a

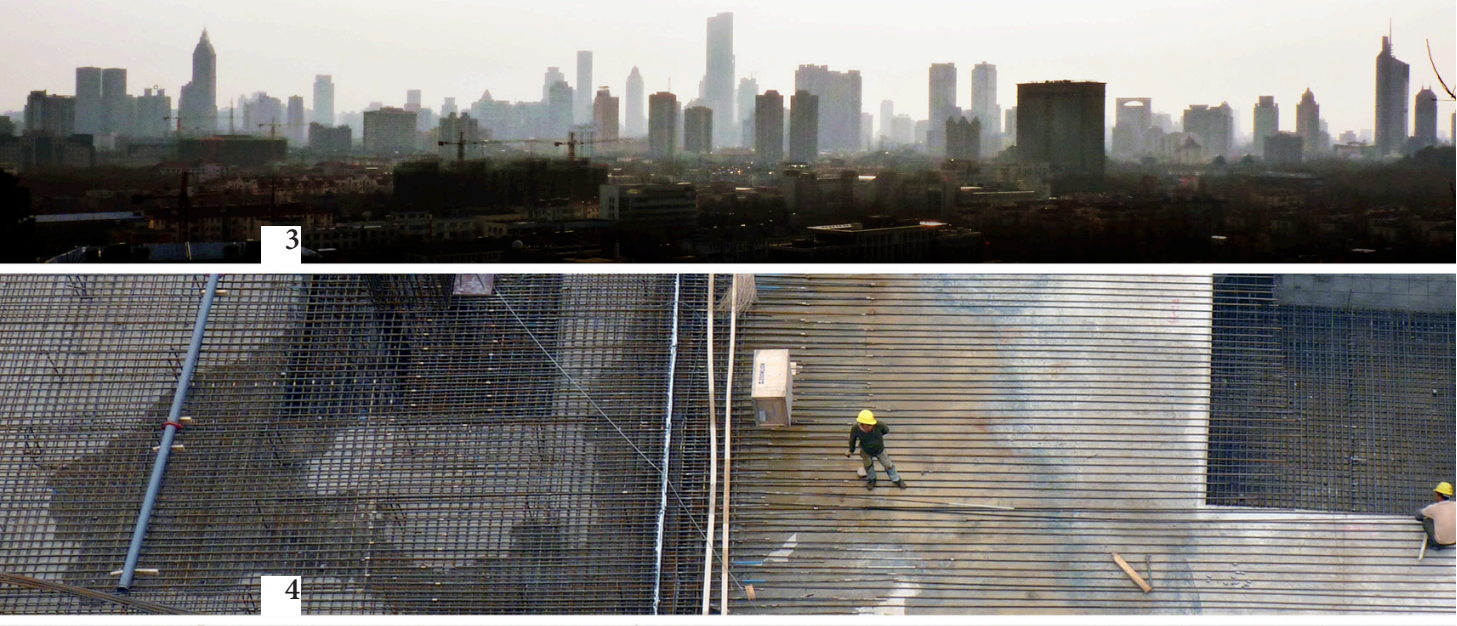

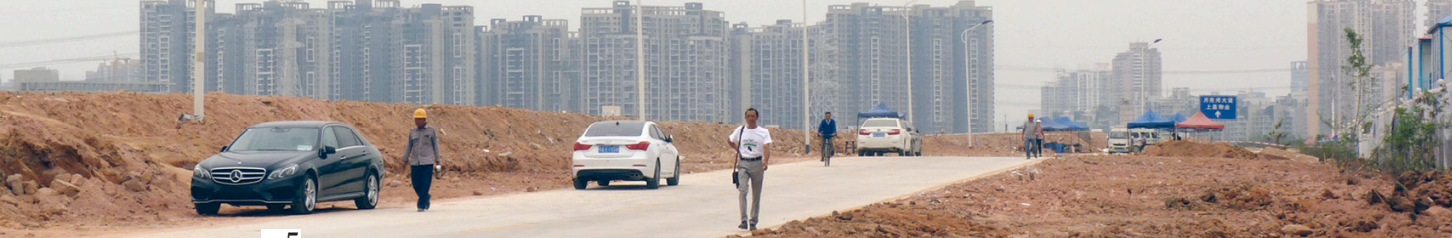

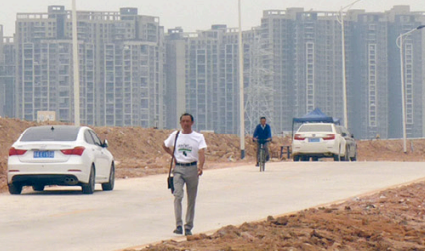

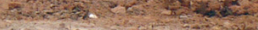

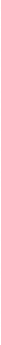

